\title{
Ultimate salvation: feasibility of NOTES for complications of ERCP and endoscopic ultrasound-guided procedures
}

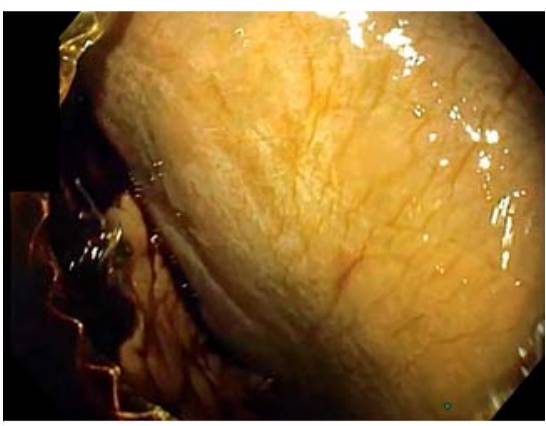

- Fig. 1 Peritoneal access through the lumen-apposing metal stent.

A 60-year-old woman with a history of morbid obesity status post sleeve gastrectomy 2 months prior to presentation arrived at the emergency department with painless jaundice. Computed tomography (CT) revealed a 3-cm pancreatic head mass. Endoscopic ultrasound (EUS) with a fine needle biopsy was performed. However, endoscopic retrograde cholangiopancreatography (ERCP) for biliary decompression was complicated by a duodenal perforation due to a preexisting severe duodenal stricture, which was managed with Ovesco clip placement [1]. Because further endoscope passage was prohibited, EUS-guided hepaticogastrostomy was then performed [2].

A 19-gauge access needle was used to puncture the dilated left hepatic duct (7 mm). Cholangiogram showed a severely dilated common bile duct to $20 \mathrm{~mm}$ with distal obstruction and dilated intrahepatic ducts. A guidewire was advanced through the needle into the left intrahepatic duct but could not cross the ampulla. Balloon dilation was used to create a fistulous tract. A $10-\mathrm{mm} \times 6-\mathrm{cm}$ fully covered self-expanding metal stent (FCSEMS) was deployed with its distal end in the left intrahepatic duct, but the proximal end did not cross into the stom-
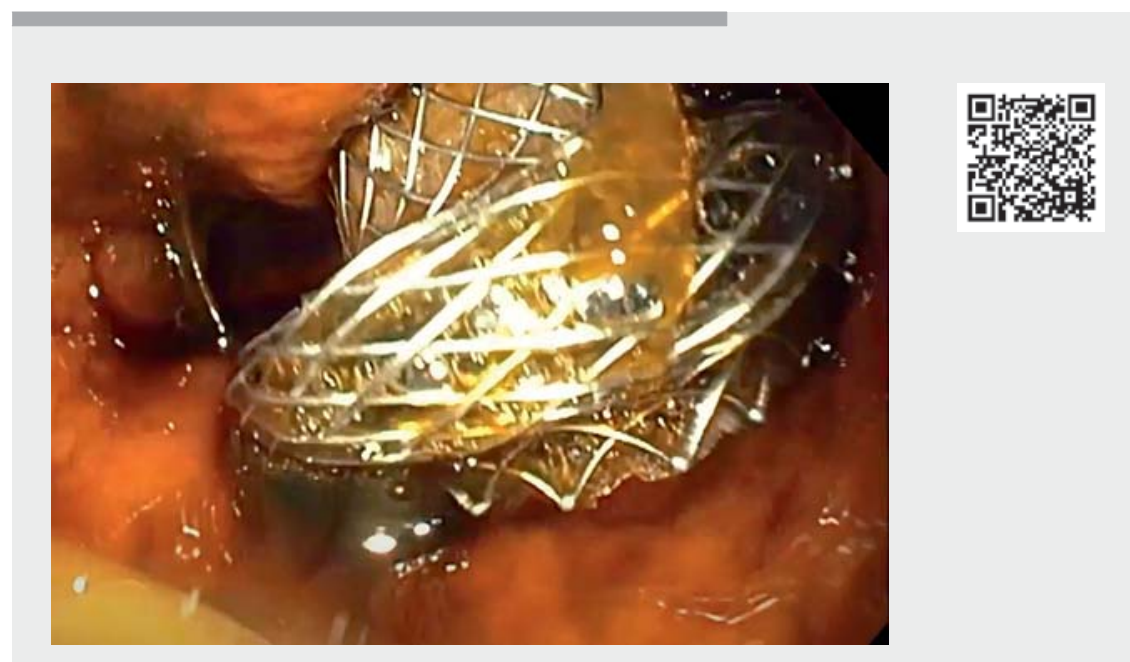

$\checkmark$ Video 1 Transgastric access into the peritoneal space to access a migrated lumen-apposing metal stent.

ach likely owing to scar tissue from prior sleeve gastrectomy. We dilated the tract to $8 \mathrm{~mm}$ and attempted to deploy a second, bridging FCSEMS within the prior one, however it migrated into the peritoneum, as seen on fluoroscopy. The procedure was then converted to a natural orifice transluminal endoscopic surgery (NOTES) ( Video 1). A 14-gauge needle was used to decompress the abdominal compartment. A $15-\mathrm{mm} \times 10-\mathrm{mm}$ lumen-apposing metal stent (LAMS) was deployed within the gastric fistula with the distal end in the peritoneum [3]. A gastroscope was passed through the LAMS and advanced into the peritoneum to the location of the stent [4] ( $>$ Fig. 1). A rat tooth forceps was used to successfully remove the LAMS and the opening was closed with another over-the-scope clip.

Under EUS guidance, the first FCSEMS within the left intrahepatic duct was accessed with a 19-gauge access needle, a wire was passed, balloon dilation per- formed, and a 10-mm $\times 6-\mathrm{cm}$ FCSEMS was successfully deployed to bridge the prior stent. Both stents were anchored with a double pigtail plastic stent. The patient remained hospitalized with placement of a duodenal stent; she resumed oral intake within 3 days of the procedure. She was diagnosed with pancreatic adenocarcinoma and began chemotherapy as an outpatient.

Expected and unexpected intraprocedural complications can be effectively managed endoscopically with currently available equipment with enough procedural alternatives to achieve safe and successful biliary drainage in a patient with post-surgical anatomy. Experience with therapeutic EUS combined with NOTES holds an important role in the salvage of significant complications of EUSguided procedures.

Endoscopy_UCTN_Code_CPL_1AJ_2AG 
Avik Sarkar has done consulting work for US Endoscopy and Obalon Therapeutics. Haroon Shahid has done consulting work for US Endoscopy. Amy Tyberg has done consulting work for NinePoint Medical, EndoGastric Solutions, and Obalon Therapeutics. Michel Kahaleh has done consulting work for Boston Scientific, Interscope Med, and Abbvie. He has received research grants from Boston Scientific, Emcision, Conmed, Pinnacle, Cook, Gore, Merit, and Olympus.

The authors

Marina Kim, Romy Bareket, Mishal Reja, Avik Sarkar, Haroon Shahid, Amy Tyberg, Michel Kahaleh (D)

Department of Gastroenterology \& Hepatology, Rutgers Robert Wood Johnson University Hospital, New Brunswick, New Jersey, USA

\section{Michel Kahaleh, MD}

Department of Gastroenterology, Robert Wood Johnson University Hospital, 1 RWJ Place, MEB 464, New Brunswick, NJ 08901, USA

Fax: +1-732-235-7307

mkahaleh@gmail.com

\section{References}

[1] labichino G, Eusebi LH, Palamara MA et al. Performance of the over-the-scope clip system in the endoscopic closure of iatrogenic gastrointestinal perforations and post-surgical leaks and fistulas. Minerva Gastroenterol Dietol 2018; 64: 75-83

[2] Ogura T, Higuchi K. Technical tips for endoscopic ultrasound-guided hepaticogastrostomy. World J Gastroenterol 2016; 22: 3945-3951

[3] Marrache MK, Itani MI, Farha J et al. Endoscopic gastrointestinal anastomosis: a review of established techniques. Gastrointest Endosc 2021; 93: 34-46

[4] Bernhardt J, Sasse S, Ludwig K et al. Update in natural orifice translumenal endoscopic surgery (NOTES). Curr Opin Gastroenterol 2017; 33: 346-351
Bibliography

Endoscopy 2022; 54: E100-E101

DOI 10.1055/a-1394-5872

ISSN 0013-726X

published online 30.3.2021

(c) 2021. Thieme. All rights reserved.

Georg Thieme Verlag KG, Rüdigerstraße 14 ,

70469 Stuttgart, Germany

\section{ENDOSCOPY E-VIDEOS}

https:/|eref.thieme.de/e-videos

回回 Endoscopy E-Videos is an open access online section, 回解: reporting on interesting cases and new techniques in gastroenterological endoscopy. All papers include a high quality video and all contributions are freely accessible online. Processing charges apply (currently EUR 375), discounts and wavers acc. to HINARI are available.

This section has its own submission website at https://mc.manuscriptcentral.com/e-videos 